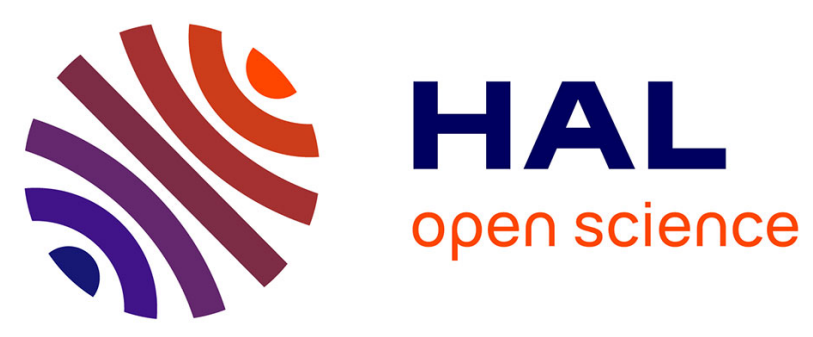

\title{
Poor glycemic control in type 2 diabetes in the South of the Sahara: the issue of limited access to an HbA1c test
} Alioune Camara, Naby M. Baldé, Joelle Sobngwi-Tambekou, P André, André P. Kengne, Mansour M. Diallo, Alain P. K. Tchatchoua, Amadou Kaké, Sylvie Ngamani, Beverley Balkau, et al.

\section{To cite this version:}

Alioune Camara, Naby M. Baldé, Joelle Sobngwi-Tambekou, P André, André P. Kengne, et al.. Poor glycemic control in type 2 diabetes in the South of the Sahara: the issue of limited access to an HbA1c test. Diabetes Research and Clinical Practice, 2015, 108 (1), pp.187-192. 10.1016/j.diabres.2014.08.025 . hal-01077373

\section{HAL Id: hal-01077373 \\ https://hal-univ-rennes1.archives-ouvertes.fr/hal-01077373}

Submitted on 24 Oct 2014

HAL is a multi-disciplinary open access archive for the deposit and dissemination of scientific research documents, whether they are published or not. The documents may come from teaching and research institutions in France or abroad, or from public or private research centers.
L'archive ouverte pluridisciplinaire HAL, est destinée au dépôt et à la diffusion de documents scientifiques de niveau recherche, publiés ou non, émanant des établissements d'enseignement et de recherche français ou étrangers, des laboratoires publics ou privés. 


\section{Accepted Manuscript}

Title: Poor glycemic control in type 2 diabetes in the South of the Sahara: the issue of limited access to an HbA1c test

Author: Alioune Camara Naby M. Baldé Joelle

Sobngwi-Tambekou André P. Kengne Mansour M. Diallo

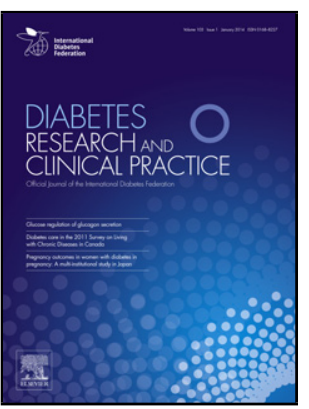

Alain P.K. Tchatchoua Amadou Kaké Ngamani Sylvie

Beverley Balkau Fabrice Bonnet Eugène Sobngwi

PII:

S0168-8227(14)00390-8

DOI: http://dx.doi.org/doi:10.1016/j.diabres.2014.08.025

Reference: $\quad$ DIAB 6147

To appear in: $\quad$ Diabetes Research and Clinical Practice

Received date: 6-11-2013

Revised date: $\quad$ 2-6-2014

Accepted date: $\quad$ 29-8-2014

Please cite this article as: A. Camara, N.M. Baldé, J. Sobngwi-Tambekou, A.P. Kengne, M.M. Diallo, A.P.K. Tchatchoua, A. Kaké, N. Sylvie, B. Balkau, F. Bonnet, E. Sobngwi, Poor glycemic control in type 2 diabetes in the South of the Sahara: the issue of limited access to an HbA1c test., Diabetes Research and Clinical Practice (2014), http://dx.doi.org/10.1016/j.diabres.2014.08.025

This is a PDF file of an unedited manuscript that has been accepted for publication. As a service to our customers we are providing this early version of the manuscript. The manuscript will undergo copyediting, typesetting, and review of the resulting proof before it is published in its final form. Please note that during the production process errors may be discovered which could affect the content, and all legal disclaimers that apply to the journal pertain. 


\title{
Poor glycemic control in type 2 diabetes in the South of the Sahara: the issue of limited
} access to an HbA1c test.

\author{
Alioune Camara, MD MSc, ${ }^{1,2}$ Naby M. Baldé, MD, ${ }^{1}$ Joelle Sobngwi-Tambekou, MD PhD, ${ }^{3}$ \\ André P. Kengne, MD PhD, ${ }^{4}$ Mansour M. Diallo, MD, ${ }^{1}$ Alain P. K Tchatchoua, MD ${ }^{5}$ \\ Amadou Kaké, MD, ${ }^{1}$ Ngamani Sylvie, BScN,${ }^{5}$ Beverley Balkau, PhD,${ }^{6}$
}
${ }^{1}$ Department of Endocrinology, University Hospital, Conakry, Guinea 2 INSERM, CIC 0203, University Hospital of Pontchaillou, Rennes, France ${ }^{3}$ Catholic University of Central Africa, Yaounde, Cameroon
${ }^{4}$ Non-Communicable Diseases Research Unit, South African Medical Research Council \& University of Cape Town, Cape Town, South Africa
${ }^{5}$ Central Hospital and Faculty of medicine and biomedical sciences university, Yaounde, Cameroon
${ }^{6}$ INSERM, U1018, University Paris Sud 11, Paris, France
${ }^{7}$ Departments of Endocrinology, University Hospital, Rennes, France
${ }^{8}$ Institute of Health \& Society, Newcastle University, Newcastle upon Tyne, United Kingdom

\section{Abstract 225 words}

Main text 2273 words

28 references

\section{Tables}

Correspondance to:

\section{CAMARA Alioune}

INSERM, CIC 0203, University Hospital of Pontchaillou, Rennes, France

Université de Rennes 1 . CHU de Rennes.

Faculté de Médecine. 35043 Rennes Cedex.

Tel: +33223234713 (secrétariat) or +33299268652 (bureau)

aliounec@gmail.com 
1 Abstract

2

3 Background: - Management of type 2 diabetes remains a challenge in Africa. The objective of

4 this study was to evaluate the prevalence and predictors of poor glycemic control in patients

5 with type 2 diabetes living in sub-Saharan.

6 Patients and methods: - This was a cross-sectional study involving 1267 people $(61 \%$

7 women) with type 2 diabetes (mean age 58 years) recruited across health facilities in

8 Cameroon and Guinea. Predictors of poor glycemic control (HbAlc $\geq 7.0 \%(53 \mathrm{mmol} / \mathrm{mol}))$

9 were investigated via logistic regressions.

10 Results: - The mean body mass index was $27.4 \pm 5.8 \mathrm{~kg} / \mathrm{m}^{2}$, and $74 \%$ of patients had poor

11 glycemic control. Predictors of poor glycemic control in multivariable regression models were

12 recruitment in Guinea [odd ratio: 2.91 (95\% confidence interval 2.07 to 4.11 )], age $<65$ years

$13[1.40(1.04$ to 1.88$)]$, diabetes duration $\geq 3$ years [2.36 (1.74 to 3.21)], treatment with: oral

14 glucose control agents [3.46 (2.28 to 5.26)], insulin alone or with oral glucose control agents

$15 \quad$ [7.74 (4.70 to 12.74)] and absence of a previous HbA1c measurement in Guinea [2.96 (1.30 to

16 6.75)].

17 Conclusion: - Poor control of blood glucose is common in patients with type 2 diabetes in

18 these two countries. Limited access to HbA1c appears to be a key factor associated with poor

19 glycemic control in Guinea, and should be addressed by health policies targeting

20 improvement in the outcomes of diabetes care.

21

22 Keywords: Type 2 diabetes, glycemic control, sub-Saharan Africa 


\section{1. Introduction}

2

3 Type 2 diabetes is a common and rapidly growing chronic non-communicable disease

4 worldwide [1], including in sub-Saharan Africa [2]. The long-term microvascular and

5 macrovascular complications of diabetes are responsible for significant morbidity and

6 mortality. The growing population of people in need of care for diabetes is a challenge for

7 low-income countries where non-communicable diseases are adding to the burden of

8 communicable diseases [3].

9 Several large clinical trials have demonstrated the beneficial effect of glycemic

10 control on the development of long-term complications of diabetes [4]. Despite this evidence,

11 a high proportion of patients with diabetes remains poorly controlled [5]. This is the case in

12 Africa where a large number of people with diabetes do not reach the recommended HbA1c

13 targets [6]. The difficulties to achieve an appropriate glycemic control in developing countries

14 are likely due to a limited access to adequate health services, poor education level, reduced

15 access to medical education and a lack of monitoring of glucose control. The magnitude of

16 poor glycemic control in patients with type 2 diabetes in Africa has not been extensively

17 investigated, nor have the predictors of poor glycemic control received greater attention in

18 this setting.

19 The main aim of this study was to determine the prevalence and investigate the

20 predictors of poor glycemic control in patients with type 2 diabetes across outpatient diabetes

21 clinics in Cameroon and Guinea. We specifically investigated whether prior measures of

22 HbA1c affect subsequent glycemic control. 


\section{2. Population and methods}

2

3

4

5

\subsection{Source of data}

Patients with type 2 diabetes included in the current study were recruited and examined as part of the baseline evaluation of the project "Improving access to HbA1c in sub-Saharan Africa", which has been described previously [7]. In brief, data were collected over a one year period between 2009 and 2010 and included demographics, history of diabetes, blood pressure and anthropometric measurements, fasting blood glucose and glycated haemoglobin (HbAlc).

\subsection{Study sites and population}

Patients were recruited in 10 diabetes management centers including six regional centers in Cameroon (a Central African country with 18 million inhabitants) and four regional centers in Guinea (a West African country with 10 million inhabitants). The centres were either university hospitals $(\mathrm{UH})$ where patients were seen by endocrinologists or regional hospitals (RH) where patients were seen by general physicians or diabetologists. Prior to the study "Improving access to HbA1c in sub-Saharan Africa", these centers monitored metabolic control of patients with fasting capillary blood glucose. The study protocol was approved by the Ethics Committees of the Ministries of Public Health in Cameroon and Guinea. Participants were informed of the purpose of the study and signed an informed consent. Between August 2009 and October 2010, 1349 patients with type 1 or type 2 diabetes were selected at outpatient visits. The inclusion criteria were: being diagnosed with diabetes since at least one year and being 16 years of age or older. For the current analyses, patients with missing data on the duration of diabetes and age were excluded $(n=17)$, as well as those with type 1 diabetes $(n=65)$. Thus, data from 1267 patients with type 2 diabetes were analysed.

\subsection{Measurements and operational definition}

In this study, HbA1c was measured in a capillary blood sample by spectrophotometry using the Biorad ${ }^{\circledR}$ IN2IT devices [8,9]. A good glycemic control was defined as HbA1c $<7.0 \%(<53 \mathrm{mmol} / \mathrm{mol})[10]$.

The following data were collected: country of recruitment, health facility (University or Regional hospital), gender (Female or Male), age (dichotomized into $<65$ or $\geq 65$ years), marital status (married, single), level of education (Illiterate, $\leq$ High school, $>$ High school), employment (employed or unemployed), duration of diabetes (grouped as 1-2 and $\geq 3$ years), 
1 treatment of diabetes (categorized as diet only, oral glucose control agents alone, insulin alone

2 or with oral glucose control agents), self-monitoring of blood glucose (yes or no), waist and

3 hip circumferences. Among the 350 subjects who were treated with insulin, information about

4 the number of injections per day was available for 262 patients who were grouped as 1 and 2-

53 injections per day. The socioeconomic status was based on the employment status and level

6 of education. The body mass index (BMI) was calculated using Quetelet's index (weight /

7 height $\left.^{2}\right)$ and expressed in kilograms per meters square $\left(\mathrm{kg} / \mathrm{m}^{2}\right)$ and was further dichotomized

8 into $<25$ and $\geq 25 \mathrm{~kg} / \mathrm{m}^{2}$.

9 The American Diabetes Association definition of hypertension was applied: i.e.

10 systolic/diastolic blood pressure $\geq 130 / 80 \mathrm{mmHg}$ or antihypertensive treatment [10]. The

11 patients were classified for hypertension status as normal, unknown hypertension, known

12 hypertension with treatment and known hypertension without treatment.

\subsection{Statistical analysis}

Data are presented as mean $\pm \mathrm{SD}$ or as [median (quartile 1, quartile 3)] for continuous variables and as count (\%) for categorical variables. The Pearson correlation coefficient was used to measure the continuous association between $\mathrm{HbA1c}$ and fasting glucose. Patients

18 from Cameroon and Guinea were combined for the analysis the predictors of poor glycemic 19 control.

20 Predictors with $\mathrm{p} \leq 0.30$ in univariable analysis were entered into a multivariable 21 logistic regression models, and factors associated with poor glycemic control retained from backward selections. Interaction terms were tested and those significant at $\mathrm{p}<0.10$ were added to the final model. Odds ratios and $95 \%$ confidence intervals were calculated and a value of $p<0.05$ was considered statistically significant. The quality of the final model was verified by the Hosmer and Lemeshow fit test and the area under receiver operating characteristic curve. Analyses used SAS software (version 9.3, SAS Institute, Cary, NC). 


\section{1}

2

3

4

5

6

\section{Results}

\subsection{Characteristics of the study population}

The characteristics of the 1267 patients with type 2 diabetes included in the study are presented in Table 1; 60\% were from Cameroon; $54 \%$ were followed in university hospitals; $30 \%$ were illiterate. The mean duration of diabetes was $7.6 \pm 6.3$ years [median 6 years $\left(25^{\text {th }}-\right.$ $75^{\text {th }}$ percentiles: $\left.3-10\right)$ ]. The mean age was $58.4 \pm 10.5$ years [median 58 years $(52-65)$ ]. They were mostly treated with an oral oral glucose control agents alone ( $62 \%$ overall, $66 \%$ in Cameroon and $56 \%$ in Guinea). Among patients who were receiving insulin, the information of number of injections per day was available for 262. Most of them (90.1\%) had two or three injections per day. In all $39 \%$ of patients reported that they self-monitored their blood glucose, more frequently in Guinea (42\%) than in Cameroon (38\%). Only $21 \%$ had had a previous determination of $\mathrm{HbAlc}$ prior to the study. The mean body mass index (BMI) was $27.4 \pm 5.8 \mathrm{~kg} / \mathrm{m}^{2}$, which was significantly higher in Cameroon $\left(28.6 \pm 6.2 \mathrm{~kg} / \mathrm{m}^{2}\right)$ than in 5 Guinea $\left(25.5 \pm 4.7 \mathrm{~kg} / \mathrm{m}^{2}\right) ; \mathrm{p}<0.001$. Among the 962 subjects ( $\left.76 \%\right)$ with hypertension, only $42 \%$ were on antihypertensive therapy at inclusion.

(8)

\subsection{Glycemic and blood pressure control}

Among the 1267 patients, 939 (74\%) had an HbAlc $\geq 7.0 \%$ ( $\geq 53 \mathrm{mmol} / \mathrm{mol})$ of whom 388 (41\%) had an $\mathrm{HbAlc} \geq 10.0 \%$ ( $\geq 86 \mathrm{mmol} / \mathrm{mol}$ ) (Table 2 ). The frequency of poor glycemic control was $74 \%$ overall and significantly higher in Guinea (84\%) than in Cameroon (68\%); $\mathrm{p}<0.001$. The average $\mathrm{HbAlc}$ was $8.9 \pm 2.5 \%(74 \pm 4 \mathrm{mmol} / \mathrm{mol})$ and fasting glucose averaged $9.4 \pm 4.3 \mathrm{mmol} / \mathrm{L}$. HbAlc and fasting glucose were significantly and positively correlated with each other $(r=0.68, p<0.001)$. A blood pressure below $130 / 80 \mathrm{mmHg}$ was observed in only 250 subjects (20\%) and only 75 (6\%) patients had both glycemia and blood pressure values below the recommended thresholds.

\subsection{Univariable predictors of poor glycemic control} recruitment in Guinea [odds ratio: 2.52 (95\% confidence interval: 1.89 to 3.34 )] and age under 65 years [1.33 (1.01 to 1.75)]. Diabetes was more likely to be poorly controlled among those with little education [1.53 (1.13 to 2.07)] (Table 2). Compared to the patients with $<$ high school, those with $\geq$ high school were the most likely to have poor glycemic control even though this did not reach statistical significance. Clinical and behavioural factors 
1 associated with poor glycemic control were the presence of high diastolic blood pressure

2 [1.39 (1.07 to 1.80)], absence of previous measures of HbA1c [1.68 (1.25 to 2.25)], diabetes

3 duration $\geq 3$ years [2.61 (1.97 to 3.47)], treatment with oral glucose control agents [2.55 (1.75

4 to 3.72)], insulin alone or with oral glucose control agents [6.25 (3.94 to 9.91)]. Those who

5 had two or more insulin injections per day had a significantly higher odds ratio of having a

6 poor glycemic control [OR: $2.98 ; 95 \% \mathrm{CI}$ : (1.14 to 7.75)] than those with one injection per

7 day. Normal weight $\left(\mathrm{BMI}<25 \mathrm{~kg} / \mathrm{m}^{2}\right)$ was also associated with poor glycemic control [1.43

8 (1.09 to 1.88$)]$.

9

\subsection{Multivariable predictors poor glycemic control}

11 The variables significantly associated with poor glycemic control based on a threshold 12 of $\mathrm{p}<0.30$ in univariate models, were entered altogether in the same multivariable model.

13 Then backward selection procedures were applied to retain the final predictors (Table 3). Of

14 all the interactions terms tested, only the interaction between country and previous measurement of $\mathrm{HbA1c}(\mathrm{p}=0.06)$ was significant and was therefore added to the final model which included: recruitment in Guinea [2.91 (2.07 to 4.11)], age $<65$ years [1.40 (1.04 to

17 1.88)], diabetes duration $\geq 3$ years [2.36 (1.74 to 3.20)], treatment with oral glucose control 18 agents alone [3.46 (2.28 to 5.26)], insulin alone or with oral glucose control agents [7.74 (4.70 19 to 12.74)] and no previous measurement of HbA1c in Guinea [2.96 (1.30 to 6.75)]. The level 20 of education, the body mass index, the diastolic blood pressure and the number of insulin 21 injections were not significantly related to the glycemic control in the multivariate model. 22 The Hosmer and Lemeshow chi-square statistic for the final multivariable model was $231.50(\mathrm{p}=0.98)$; and the area under the ROC curve was $73 \%$. 


\section{1}

2

3

4

5

6

7

\section{Discussion}

This study has revealed that three out of four patients with type 2 diabetes in the participating centres in two Sub-Sarahan African countries (Cameroon and Guinea), had poor glycemic control and only $6 \%$ were at target control levels for glycemia and blood pressure values. On average, the diagnosed duration of diabetes was eight years at enrolment in the study. Recruitment in Guinea, younger age, longer duration of diabetes, treatment with oral glucose control agents with or without insulin, and lack of previous $\mathrm{HbAlc}$ measures were the main predictors of poor glycemic control.

High frequencies of poor glycemic control for type 2 diabetes, defined by HbAlc thresholds of $6.5 \%(48 \mathrm{mmol} / \mathrm{mol})$ or $7.0 \%(53 \mathrm{mmol} / \mathrm{mol})$, have been reported across regions around the world. In "The International Diabetes Mellitus Practice Study" (IDMPS) [11], conducted in low-income countries, the frequency of poor glycemic control in type 2 diabetes ranged from $63 \%$ in Asia to $64 \%$ in Eastern Europe and Latin America. In the" Diabcare Africa study" [6] conducted across six African countries, the prevalence of HbAlc $\geq 6.5 \%$ $(\geq 48 \mathrm{mmol} / \mathrm{mol}$ ) was $71 \%$.

After adjusting for the others variables the level of education was not associated with poor glycemic control. Our result in terms of level of education was similar to that reported in Michigan [12]. However, a low level of education was associated with poor glycemic control in Jordan [13] and in Mexican Americas in the United States [14].

Our study confirmed that a longer duration of diabetes is significantly associated with poor glycemic control $[15,16]$, as observed in the natural history of the disease. Furthermore, among patients with longstanding diabetes, those with normal BMI were more likely to have poor glycemic control, possibly reflecting the effect of weight loss in the context of poor glycemic control [17]. We also found young age to be associated with poor glycemic control, in line with some reports in the literature [18-20] but not all [15,21]. Treatment with oral glucose lowering agents or insulin was associated with poorer glycemic control, most likely reflecting the phenomenon of reverse causality, i.e. more intensive treatment being required by the presence of elevated glycaemia. A poor glycemic control was more frequently observed among patients who were treated with drugs (oral agents and / or insulin), but more so in those who were treated with insulin (alone or in combination with oral drugs). Some studies $[22,23]$ have reported a link between poor glycemic control and treatment with a combination of oral glucose lowering agents and insulin. These results may reflect a delay in the introduction of insulin in the treatment of patients with poor glycemic control $[4,24]$ but also to the intensification of insulin therapy with insufficient insulin doses. 
Affordable access to $\mathrm{HbAlc}$ measurements for people with diabetes remain a

2 challenge in developing countries [25], which may affect the quality of care and explain the

3 correlation found in our study lack of access to HbA1c and poor glycemic control in Guinea.

4 Indeed, HbA1c measurement is the cornerstone in strategies for initiating and intensifying

5 treatments for people with diabetes [26]. Availability of $\mathrm{HbA} 1 \mathrm{c}$ has been associated with

6 improved glycemic control [27], both by positively affecting the attitude of healthcare

7 providers [28], and improving adherence to treatments in patients.

8 The cross-sectional nature of this study limits inferences about causality of relationships

9 between the predictors identified in the study and poor diabetes control in our sample. This

10 study is also limited by the lack of information on physical activity, psychological status, and

11 compliance to treatment, other factors that may influence glycemic control and the outcomes

12 of diabetes care.

13 In conclusion, the percentage of patients with poor glycemic control is as high in

14 Cameroon and Guinea as has been reported in a number of other countries. Limited access to $15 \mathrm{HbA} 1 \mathrm{c}$ monitoring appears to be a contributing factor. These findings suggest that increased 16 access to an $\mathrm{HbA1c}$ test could be an important step in health policies to improve glycemic 17 control in patients with type 2 diabetes from Sub Sahara Africa. 


\section{Acknowledgments}

2

3 This project is supported by a grant from the BRIDGES International Diabetes Federation, a

4 project of the International Diabetes Federation, supported by an educational grant from Eli

$5 \quad$ Lilly and Company

6

7 We are grateful to Jacques Chaperon for his invaluable contribution (Department of Public

8 Health, University of Rennes 1, Faculty of Medicine, retired). We also thank all the health

9 professionals who contributed to the recruitment and follow-up of patients in the current 10 study.

11 


\section{References}

[1] Guariguata L, Whiting DR, Hambleton I, Beagley J, Linnenkamp U, Shaw JE. Global estimates of diabetes prevalence in adults for 2013 and projections for 2035 for the IDF Diabetes Atlas. Diabetes Res Clin Pract 2014. 103 (2): 137-149

[2] Hall V, Thomsen RW, Henriksen O, Lohse N. Diabetes in Sub Saharan Africa 19992011: Epidemiology and public health implications. a systematic review. BMC Public Health 2011;11(1):564.

[3] Mbanya JCN, Motala AA, Sobngwi E, Assah FK, Enoru ST. Diabetes in sub-Saharan Africa. The Lancet 2010;375(9733):2254-66.

[4] UK Prospective Diabetes Study (UKPDS) Group. Intensive blood-glucose control with sulphonylureas or insulin compared with conventional treatment and risk of complications in patients with type 2 diabetes (UKPDS 33). The Lancet 1998;352(9131):837-53.

[5] Karter AJ, Moffet HH, Liu J, Parker MM, Ahmed AT, Ferrara A, et al. Achieving good glycemic control: initiation of new antihyperglycemic therapies in patients with type 2 diabetes from the Kaiser Permanente Northern California Diabetes Registry. Am J Manag Care 2005;11(4):262.

[6] Sobngwi E, Ndour-Mbaye M, Boateng KA, Ramaiya KL, Njenga EW, Diop SN, et al. Type 2 diabetes control and complications in specialised diabetes care centres of six sub-Saharan African countries: The Diabcare Africa study. Diabetes Res Clin Pract 2012;95(1):30-6.

[7] Sobngwi E, Balde N. de la théorie à la pratique: améliorer l'accès à la mesure de l'Hba. Thérapies Émergentes Pour Diabète 2011;36.

[8] Martin M, Leroy N, Sulmont V, Gillery P. Evaluation of the In2it@ analyzer for HbA1c determination. Diabetes Metab 2010;36(2):158-64.

[9] Marzullo C, Minery M, Guemazi F, Stojiljkovic D, Benoît M. Dosage délocalisé de l'hémoglobine A1c sur l'analyseur In2it ${ }^{\mathrm{TM}}$ dans le cadre d'une consultation de diabétologie pédiatrique. Immuno-Anal Biol Spéc 2010;25(1):34-7.

[10] American Diabetes Association. Standards of Medical Care in Diabetes--2014. Diabetes Care 2014;37(Supplement_1):S14-S80.

[11] Chan JCN, Gagliardino JJ, Baik SH, Chantelot J-M, Ferreira SRG, Hancu N, et al. Multifaceted Determinants for Achieving Glycemic Control The International Diabetes Management Practice Study (IDMPS). Diabetes Care 2009;32(2):227-33.

[12] Blaum CS, Velez L, Hiss RG, Halter JB. Characteristics related to poor glycemic control in NIDDM patients in community practice. Diabetes Care 1997;20(1):7-11.

[13] Khattab M, Khader YS, Al-Khawaldeh A, Ajlouni K. Factors associated with poor glycemic control among patients with Type 2 diabetes. J Diabetes Complications 2010;24(2):84-9.

[14] Otiniano ME, Al Snih S, Goodwin JS, Ray L, AlGhatrif M, Markides KS. Factors associated with poor glycemic control in older Mexican American diabetics aged 75 years and older. J Diabetes Complications 2012;26(3):181-6.

[15] Benoit S, Fleming R, Philis-Tsimikas A, Ji M. Predictors of glycemic control among patients with type 2 diabetes: a longitudinal study. BMC Public Health 2005;5(1):36.

[16] Verma M, Paneri S, Badi P, Raman PG. Effect of increasing duration of diabetes mellitus type 2 on glycated hemoglobin and insulin sensitivity. Indian J Clin Biochem 2006;21(1):142-6.

[17] Arner P, Pollare T, Lithell H. Different aetiologies of type 2 (non-insulin-dependent) diabetes mellitus in obese and non-obese subjects. Diabetologia 1991;34(7):483-7. 
[18] Chiu CJ, Wray LA. Peer Reviewed: Factors Predicting Glycemic Control in MiddleAged and Older Adults With Type 2 Diabetes. Prev Chronic Dis 2010;7(1).

[19] El-Kebbi IM, Cook CB, Ziemer DC, Miller CD, Gallina DL, Phillips LS. ASsociation of younger age with poor glycemic control and obesity in urban african americans with type 2 diabetes. Arch Intern Med 2003;163(1):69-75.

[20] Rothenbacher D, Rüter G, Saam S, Brenner H. Younger patients with type 2 diabetes need better glycaemic control: results of a community-based study describing factors associated with a high HbAlc value. Br J Gen Pract 2003;53(490):389.

[21] Ko S-H, Park S-A, Cho J-H, Ko S-H, Shin K-M, Lee S-H, et al. Influence of the Duration of Diabetes on the Outcome of a Diabetes Self-Management Education Program. Diabetes Metab J 2012;36(3):222.

[22] Al-Nuaim AR, Mirdad S, Al-Rubeaan K, Al-Mazrou Y, Al-Attas O, Al-Daghari N. Pattern and factors associated with glycemic control of Saudi diabetic patients. Ann Saudi Med 1998;18(2):109-12.

[23] Valle T, Koivisto VA, Reunanen A, Kangas T, Rissanen A. Glycemic control in patients with diabetes in Finland. Diabetes Care 1999;22(4):575-9.

[24] Fox KM, Gerber PRA, Bolinder B, Chen J, Kumar S. Prevalence of inadequate glycemic control among patients with type 2 diabetes in the United Kingdom general practice research database: A series of retrospective analyses of data from 1998 through 2002. Clin Ther 2006;28(3):388.

[25] Rahlenbeck SI. Monitoring of glycemic balance in diabetics living in Africa: a review of glycated hemoglobin measurement methods. Santé Montrouge Fr 2002;12(3):337-41.

[26] Inzucchi SE, Bergenstal RM, Buse JB, Diamant M, Ferrannini E, Nauck M, et al. Management of hyperglycemia in type 2 diabetes: a patient-centered approach: position statement of the American Diabetes Association (ADA) and the European Association for the Study of Diabetes (EASD). Diabetes Care 2012;35(6):1364-79.

[27] Cagliero E, Levina EV, Nathan DM. Immediate feedback of HbA1c levels improves glycemic control in type 1 and insulin-treated type 2 diabetic patients. Diabetes Care 1999;22(11):1785-9.

[28] Dorchy H, Roggemans MP, Willems D. Glycated hemoglobin and related factors in diabetic children and adolescents under 18 years of age: a Belgian experience. Diabetes Care 1997;20(1):2-6. 
1 Table 1: Characteristic (mean $\pm \mathrm{SD}$ or $\mathrm{n}(\%)$ ) of the 1267 type 2 diabetes patients from 2 Cameroon and Guinea.

3

\begin{tabular}{|c|c|c|c|c|c|c|}
\hline & & $\begin{array}{l}\text { otal } \\
1267)\end{array}$ & & $\begin{array}{l}\text { neroon } \\
=766 \text { ) }\end{array}$ & & $\begin{array}{l}\text { uinea } \\
=501 \text { ) }\end{array}$ \\
\hline Age (years) & 58.4 & $( \pm 10.5)$ & 58.7 & $( \pm 10.7)$ & 57.8 & $( \pm 10.1)$ \\
\hline Monitoring site: University Hospital & 688 & $(54 \%)$ & 380 & $(50 \%)$ & 308 & $(61 \%)$ \\
\hline Women & 775 & $(61 \%)$ & 461 & $(60 \%)$ & 314 & $(63 \%)$ \\
\hline Married & 881 & $(70 \%)$ & 499 & $(65 \%)$ & 382 & $(76 \%)$ \\
\hline Unemployed & 612 & $(48 \%)$ & 383 & $(50 \%)$ & 229 & $(46 \%)$ \\
\hline Level of education & & & & & & \\
\hline Illiterate & 378 & $(30 \%)$ & 162 & $(21 \%)$ & 216 & $(43 \%)$ \\
\hline$\leq$ High school & 678 & $(53 \%)$ & 500 & $(65 \%)$ & 178 & $(36 \%)$ \\
\hline >High school & 211 & $(17 \%)$ & 104 & $(14 \%)$ & 107 & $(21 \%)$ \\
\hline Treatment of diabetes & & & & & & \\
\hline Diet only & 130 & $(10 \%)$ & 53 & $(7 \%)$ & 77 & $(15 \%)$ \\
\hline oral glucose control agents alone & 787 & $(62 \%)$ & 509 & $(66 \%)$ & 278 & $(56 \%)$ \\
\hline insulin alone or with oral glucose control agents & 350 & $(28 \%)$ & 204 & $(27 \%)$ & 146 & $(29 \%)$ \\
\hline Number insulin injections per day $(n=262)$ & 1.9 & $( \pm 0.3)$ & 1.9 & $( \pm 0.4)$ & 1.9 & $( \pm 0.3)$ \\
\hline Diabetes duration (years) & 7.6 & $( \pm 6.3)$ & 7.5 & $( \pm 6.5)$ & 7.8 & $( \pm 5.9)$ \\
\hline Previous measurement of $\mathrm{HbA} 1 \mathrm{c}$ & 266 & $(21 \%)$ & 232 & $(30 \%)$ & 34 & $(7 \%)$ \\
\hline Self-monitoring of blood glucose & 498 & $(39 \%)$ & 289 & $(38 \%)$ & 209 & $(42 \%)$ \\
\hline Known hypertension & 962 & $(76 \%)$ & 534 & $(70 \%)$ & 428 & $(85 \%)$ \\
\hline $\operatorname{Hip}(\mathrm{cm})$ & 101 & $( \pm 11.4)$ & 102 & $( \pm 11.8)$ & 99.6 & $( \pm 10.7)$ \\
\hline Waist (cm) & 94.8 & $( \pm 13)$ & 96.2 & $( \pm 14.1)$ & 92.7 & $( \pm 10.6)$ \\
\hline Body mass index $\left(\mathrm{kg} / \mathrm{m}^{2}\right)$ & 27.4 & $( \pm 5.8)$ & 28.6 & $( \pm 6.2)$ & 25.6 & $( \pm 4.7)$ \\
\hline
\end{tabular}

4 
1 Table 2: Odds ratios for factors associated with poor diabetes control (HbAlc $\geq 7 \%$ ) in type 2

2 diabetes patients in Cameroon and Guinea

\begin{tabular}{|c|c|c|c|c|c|c|}
\hline \multirow{2}{*}{$\begin{array}{l}\text { Country } \\
\end{array}$} & \multicolumn{2}{|c|}{$\begin{array}{c}\mathrm{HbA} 1 \mathrm{c}<7 \% \\
(\mathrm{n}=328)\end{array}$} & \multicolumn{2}{|c|}{$\begin{array}{c}\mathrm{HbA} 1 \mathrm{c} \geq 7 \% \\
(\mathrm{n}=939)\end{array}$} & \multicolumn{2}{|c|}{$\begin{array}{c}\text { OR non adjusted } \\
(95 \% \mathrm{CI})\end{array}$} \\
\hline & & & & & & \\
\hline Cameroon & 248 & $(32 \%)$ & 518 & $(68 \%)$ & Ref & - \\
\hline Guinea & 80 & $(16 \%)$ & 421 & $(84 \%)$ & 2.52 & $1.89-3.34$ \\
\hline \multicolumn{7}{|l|}{ Monitoring site } \\
\hline University Hospital & 171 & $(25 \%)$ & 517 & $(75 \%)$ & Ref & - \\
\hline Regional Hospital & 157 & $(27 \%)$ & 422 & $(73 \%)$ & 0.89 & $0.69-1.14$ \\
\hline \multicolumn{7}{|l|}{ (2) } \\
\hline$\geq 65$ years & 102 & $(30.0 \%)$ & 238 & $(70.0 \%)$ & Ref & - \\
\hline$<65$ years & 226 & $(24.4 \%)$ & 701 & $(75.6 \%)$ & 1.33 & $1.01-1.75$ \\
\hline \multicolumn{7}{|l|}{ Sex } \\
\hline Man & 138 & $(28 \%)$ & 355 & $(72 \%)$ & Ref & - \\
\hline Woman & 190 & $(24 \%)$ & 584 & $(75 \%)$ & 1.19 & $0.93-1.54$ \\
\hline \multicolumn{7}{|l|}{ Marital status (Married) } \\
\hline No & 101 & $(26 \%)$ & 285 & $(74 \%)$ & Ref & - \\
\hline Yes & 227 & $(26 \%)$ & 654 & $(74 \%)$ & 1.02 & $0.78-1.34$ \\
\hline \multicolumn{7}{|l|}{ Employment } \\
\hline Unemployed & 169 & $(28 \%)$ & 443 & $(72 \%)$ & Ref & - \\
\hline Employed & 159 & $(24 \%)$ & 496 & $(76 \%)$ & 1.19 & $0.92-1.53$ \\
\hline \multicolumn{7}{|l|}{ Level of education } \\
\hline Illiterate & 78 & $(20.6 \%)$ & 300 & $(79.4 \%)$ & 1.53 & $1.13-2.07$ \\
\hline$\leq$ High school & 193 & $(28.5 \%)$ & 485 & $(71.5 \%)$ & Ref & - \\
\hline$>$ High school & 57 & $(27.0 \%)$ & 154 & $(73.0 \%)$ & 1.07 & $0.76-1.52$ \\
\hline \multicolumn{7}{|l|}{ Treatment of diabetes } \\
\hline Diet only & 64 & $(49.2 \%)$ & 66 & $(50.8 \%)$ & Ref & - \\
\hline oral glucose control agents alone & 217 & $(27.6 \%)$ & 570 & $(72.4 \%)$ & 2.55 & $1.75-3.72$ \\
\hline insulin alone or with oral glucose control agents & 47 & $(13.4 \%)$ & 303 & $(86.6 \%)$ & 6.25 & $3.94-9.91$ \\
\hline Number injections per day $(\mathrm{n}=202)$ & 7 & $(26.9 \%)$ & 19 & $(73.1 \%)$ & Ref & - \\
\hline $2-3$ & 26 & $(11.0 \%)$ & 210 & $(89.0 \%)$ & 2.98 & $1.14-7.75$ \\
\hline \multicolumn{7}{|l|}{ Duration of diabetes } \\
\hline$<1-3$ years & 114 & $(41.8 \%)$ & 159 & $(58.2 \%)$ & Ref & - \\
\hline$\geq 3$ years & 214 & $(21.5 \%)$ & 780 & $(78.5 \%)$ & 2.61 & $1.97-3.47$ \\
\hline \multicolumn{7}{|l|}{ Previous measurement of $\mathrm{HbAlc}$} \\
\hline 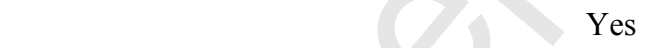 & 91 & $(34.2 \%)$ & 175 & $(65.8 \%)$ & Ref & - \\
\hline No & 237 & $(23.7 \%)$ & 764 & $(76.3 \%)$ & 1.68 & $1.25-2.25$ \\
\hline \multicolumn{7}{|l|}{ Self-monitoring of blood glucose } \\
\hline Yes & 132 & $(26.5 \%)$ & 366 & $(73.5 \%)$ & Ref & - \\
\hline No & 196 & $(25.5 \%)$ & 573 & $(74.5 \%)$ & 1.05 & $0.82-1.36$ \\
\hline \multicolumn{7}{|l|}{ Body mass index } \\
\hline$\geq 25 \mathrm{~kg} / \mathrm{m}^{2}$ & 231 & $(28.3 \%)$ & 586 & $(71.7 \%)$ & Ref & - \\
\hline$<25 \mathrm{~kg} / \mathrm{m}^{2}$ & 97 & $(21.6 \%)$ & 353 & $(78.4 \%)$ & 1.43 & $1.09-1.88$ \\
\hline \multicolumn{7}{|l|}{ Hypertension } \\
\hline known hypertension treated & 103 & $(25.6 \%)$ & 300 & $(74.4 \%)$ & 1.14 & $0.82-1.59$ \\
\hline known hypertension without treatment & 139 & $(24.9 \%)$ & 420 & $(75.1 \%)$ & 1.19 & $0.87-1.63$ \\
\hline \multicolumn{7}{|l|}{ Blood pressure systolic $\geq 130 \mathrm{mmHg}$} \\
\hline$e_{1}$ & 100 & $(28.3 \%)$ & 254 & $(71.7 \%)$ & Ref & - \\
\hline Yes & 228 & $(25.0 \%)$ & 685 & $(75.0 \%)$ & 1.18 & $0.89-1.56$ \\
\hline \multicolumn{7}{|l|}{ Blood pressure diastolic $\geq 80 \mathrm{mmHg}$} \\
\hline $\begin{array}{r}\text { No } \\
\text { Yes }\end{array}$ & $\begin{array}{l}135 \\
193 \\
\end{array}$ & $\begin{array}{l}(30.1 \%) \\
(23.6 \%)\end{array}$ & $\begin{array}{l}314 \\
625 \\
\end{array}$ & $\begin{array}{l}(69.9 \%) \\
(76.4 \%) \\
\end{array}$ & $\begin{array}{l}\text { Ref } \\
1.39 \\
\end{array}$ & $\begin{array}{c}- \\
1.07-1.80 \\
\end{array}$ \\
\hline
\end{tabular}


1 Table 3: Odds ratios (95\% confidence intervals) of factors associated independently with 2 poor glycemic control $(\mathrm{HbA} 1 \mathrm{c} \geq 7 \%)$ in type 2 diabetes patients in Cameroon and Guinea

3

\begin{tabular}{|c|c|c|}
\hline & $\begin{array}{l}\text { OR }(95 \% \mathrm{CI}) \text { without } \\
\text { interaction term }\end{array}$ & $\begin{array}{l}\text { OR }(95 \% \mathrm{CI}) \text { with } \\
\text { interaction term }\end{array}$ \\
\hline Country (Guinea) & $2.62(1.90-3.61)$ & $2.91 \quad(2.07-4.11)$ \\
\hline Age $(<65$ years $)$ & $1.39 \quad(1.03-1.88)$ & $1.40 \quad(1.04-1.88)$ \\
\hline Duration of diabetes ( $\geq 3$ years) & $2.36(1.74-3.20)$ & $2.36 \quad(1.74-3.21)$ \\
\hline \multicolumn{3}{|l|}{ Treatment of diabetes } \\
\hline oral glucose control agents alone & $3.38 \quad(2.23-5.12)$ & $3.46 \quad(2.28-5.26)$ \\
\hline insulin alone or with oral glucose control agents & $7.60 \quad(4.62-12.48)$ & $7.74 \quad(4.70-12.74)$ \\
\hline Previous measurement of $\mathrm{HbAlc}$ (none) & $1.43(1.04-1.98)$ & \\
\hline No previous measurement of $\mathrm{HbA} 1 \mathrm{c}$ in Guinea & & $2.96 \quad(1.30-6.75)$ \\
\hline No previous measurement of $\mathrm{HbA} 1 \mathrm{c}$ in Cameroon & & $1.28 \quad(0.91-1.81)$ \\
\hline
\end{tabular}

4

5 